\title{
Redefining the State's Response to Domestic Violence: Past Victories and future Challenges
}

Deborah Epstein

Georgetown University Law Center, epstein@law.georgetown.edu

This paper can be downloaded free of charge from:

https://scholarship.law.georgetown.edu/facpub/1708

http://ssrn.com/abstract=2805143

1 Geo. J. Gender \& L. 127-143

This open-access article is brought to you by the Georgetown Law Library. Posted with permission of the author. Follow this and additional works at: https://scholarship.law.georgetown.edu/facpub

Part of the Family Law Commons, and the Law and Gender Commons 


\title{
Redefining The State's Response to Domestic Violence: Past Victories and Future Challenges
}

\author{
Deborah EPSTEIN*
}

\section{INTRODUCTION}

What role should the state play in the fight against domestic violence? Although most activists in the early domestic abuse movement viewed government institutions with a robust dose of suspicion, over time they began to look to the state for substantial assistance. During this period-the late sixties and seventies-increased hope for a positive governmental role appeared to be well-founded. The civil rights, feminist, and labor movements had pushed the federal government into expanding civil liberty guarantees and economic protections. Laws were enacted prohibiting sex- and race-based discrimination, health care got a strong boost through the creation of Medicaid and Medicare, and workplace safety guarantees were expanded. And in the seventies and eighties, on the domestic violence front, state legislatures enacted civil protection order statutes that were the first laws specifically designed to protect victims of intimate abuse.

As legislatures moved ahead in establishing civil rights for women-and battered women in particular ${ }^{1}$ - activists focused on the corresponding need for a strong legislative and executive response from the criminal justice system. They called upon the state to mandate improved police response to domestic violence calls, to form special prosecutorial units dedicated to pursuing these cases, and to "treat domestic violence like any other crime." Government actors have responded and are now beginning to improve their records in imposing criminal sanctions in family abuse cases.

But as the state escalates its response to domestic violence, activists need to reassess their dependence on and trust in state power. Criminal prosecutions of batterers are occurring despite victim opposition and without regard to victims' wishes about the future of their families. Survivors who decline to testify voluntarily are being compelled to do so by subpoena, even when their testimony could result in a retaliatory assault. And battered women who have relied on a government safety net for survival are now being pushed off the welfare rolls, pressured to find jobs that often do not exist, and threatened with sanctions for failing to comply with these requirements.

This essay seeks to renew the energy of the domestic violence movement by

* Associate Professor and Director, Domestic Violence Clinic, Georgetown University Law Center, J.D., New York University School of Law, 1988. The author would like to thank Rhonda Armstrong and Erica Niezgoda for their research assistance.

1. The vast majority of domestic violence cases involve male perpetrators and female targets. Although numerous cases exist in which the gender roles are reversed, or which involve same-sex intimate abuse, I will refer to perpetrators primarily as male and targets primarily as female. 
taking stock of the significant victories that have been achieved in improving the state's response to family abuse over the past thirty years. It then encourages activists concerned about victims' rights to identify strategies to reduce the movement's profound dependence on state action and meet the critical challenges ahead. We can begin by working within the private sector to increase social support for victims and to strengthen their residential and economic communities. Such changes could reduce family violence and lessen the need for state intervention. But even if such efforts are successful, there will always be a need for government action in some cases. Activists, therefore, must find ways to strengthen the victim's role in the context of an exercise of state power. They must ensure that the government obtains the information necessary to permit and encourage a response that honors a survivor's personal view of the best course for herself and her family.

In addition, activists need to focus on the largely neglected third branch of the state-the judiciary. While legislatures and executives have responded strongly to the problem of intimate abuse, most judges lack formal education in the field and find it difficult to sympathize with victims who frequently return to their abusive partners. Judicial failure to understand the dynamics of intimate violence often results in hostile treatment of litigants and a refusal to award the full range of protections to which victims are entitled. If movement activists can find ways to train judges and improve the justice system's response to the special problems created by family abuse cases, victims will be far better served by the laws that exist on the books.

\section{Recent Victories in Redefining the State's Response to Domestic VIOLENCE}

The United States' battered women's movement grew out of the broader feminist movement of the late 1960s and early $1970 \mathrm{~s}^{2}$ During that period, activists perceived violence against women as integrally linked to gender inequality and viewed the political and legal establishment with suspicion, maintaining that it perpetuated institutional forms of sexism. ${ }^{3}$ This perception led the movement to focus initially outside of the governmental sphere, on the establishment of shelters, empowerment groups, and community education workshops. ${ }^{4}$

This distrust of the state was a natural consequence of a long history of the American legal system's approval of and complicity in violence against women. From the early colonial period onward, American courts followed British common law by affirming the husband's right of domestic chastisement. In the

2. See, e.g., Susan Schechter, The Roots of the Battered Women's Movement: Personal and Political, in Susan Schecter, WoMEn AND MaLE VIOLENCE 29-52 (1982).

3. See id.

4. See id. 
words of the Mississippi Supreme Court, this rule allowed a husband to "use salutary restraints in every case of [a wife's] misbehavior, without being subjected to vexatious prosecutions, resulting in the'mutual discredit and shame of all parties concerned."

It was not until the late nineteenth century that states finally began to move away from actually condoning a husband's use of physical force to discipline his wife. ${ }^{6}$ But many still clung to the position that in the absence of "serious" violence, the government should not interfere in the private, family realm. As late as 1873, the North Carolina Supreme Court stated: "if no permanent injury has been inflicted, nor malice, cruelty nor dangerous violence shown by the husband, it is better to draw the curtain, shut out the public gaze, and leave the parties to forget and forgive." ${ }^{17}$ This view prevailed in most states well into the twentieth century.

Given this history, it comes as no surprise that the domestic violence movement began by refusing to work cooperatively with the state. But gradually, as the enormity of the problem of intimate abuse became clear, feminist activists realized that government resources could be an essential component of an

5. Bradley v. State, 1 Miss. (1 Walker) 156, 157 (1824); see also State v. Black, 60 N.C. (Win.) 262, 263 (1864) (permitting husband "to use towards his wife such a degree of force as is necessary to control an unruly temper and make her behave herself; and unless some permanent injury be inflicted ... to gratify his own bad passions, the law will not invade the domestic forum, or go behind the curtain"); $c f$. Robbins v. State, 20 Ala. 36, 39 (1852) (observing that wife's provocation can mitigate husband's fine for assault: "if the husband was at the time ... provoked to this unmanly act by the bad behavior and misconduct of his wife, he should not be visited with the same punishment as if he had without provocation wantonly and brutally injured one whom it was his duty to nourish and protect"). The first law against wife-beating during this period was enacted in Tennessee in 1850, although it is not known whether this statute was enforced. See Elizabeth Pleck, Criminal Approaches to Family Violence, 1640-1980, in 11 Family Violence: Crime and Justice, A Review of Research 19, 29, 32 (Lloyd Ohlinet et al. eds., 1989). In some instances, sporadic periods of social awareness concerning domestic violence led to legislative prohibitions in the early 1600 s, but no such laws were passed from 1672 to 1850. Id. at 29.

6. See, e.g., Fulgham v. State, 46 Ala. 143, 146-47 (1871) (stating that privilege to chastise one's wife, "ancient though it may be, to beat her with a stick, to pull her hair, choke her, spit in her face or kick her about the floor, or to inflict upon her like indignities, is not now acknowledged by our law"); Commonwealth v. McAfee, 108 Mass. 458, 461 (1971) (declaring that "beating or striking a wife violently . . is not one of the rights conferred on a husband by the marriage"); Gorman v. State, 42 Tex. 221, 223 (1875) (noting that husband's right of control over wife does not extend to punishment and correction, but is limited to protection and self defense).

7. State v. Oliver, 70 N.C. 60, 61-62 (1873); see also State v. Buckley, 2 Del. (2 Harr.) 552 (1838) (stating that "[w]e know of no law that will authorize a husband to strike his pregnant wife a blow with his fist, such as has been inflicted on this woman. ... Any undue or excessive battery by a husband of his wife either in degree, or with improper means, [is] indictable") (emphasis added); State v. Hussey, 44 N.C. (Busb.) 123 (1852) (finding wife's testimony against her husband incompetent in all cases of assault and battery, expect where permanent injury or great bodily harm is either threatened or inflicted); Richards v. Richards, 1 Grant 389, $392-93$ (Pa. 1856) (denying divorce petition on ground that "[i]t is a sickly sensibility which holds that a man may not lay hands on his wife, even rudely, if necessary, to prevent the commission of some unlawful or criminal purpose;" a man may . . be "betrayed" .. . "into the commission of an act, or a harsh expression, for which, in a moment after, he might be repentant and sorrowful"). 
effective solution. Movement strategy shifted to a push for increased legislative and executive involvement, at first through civil protection order legislation and later through mandatory arrest laws and no-drop prosecution policies.

Despite numerous frustrations and failures over the past thirty years, the domestic violence movement has made enormous strides. The country has moved from a time when no term for intimate abuse existed in the national lexicon to an era of substantial public awareness and political will to intervene. ${ }^{8}$ Every jurisdiction has now enacted civil protection order legislation, and the vast majority of these statutes authorize the essential relief necessary for battered women to leave abusive relationships. ${ }^{9}$ These "basics" include provisions for emergency ex parte relief, ${ }^{10}$ so that victims have court-ordered protection during the potentially volatile period between the time of filing a lawsuit and trial. This is the period when the abusive partner is served with court papers demonstrating the victim's intent to leave him, which often triggers a particularly severe "separation assault." 11

Modern laws governing civil protection orders also authorize fairly comprehensive post-trial relief. In addition to the basic provisions requiring the abuser to cease his assaults and stay away from the victim, these orders may award temporary child custody, safe visitation arrangements for the non-custodial parent, and child support. ${ }^{12}$ Rapid resolution of these latter issues is critical, because one of the primary reasons that victims return to their abusive partners is the pressure created by the loss of economic support. ${ }^{13}$ For a woman with children, a child support award may be the key to freedom. Similarly, because the

8. For a detailed description of domestic violence law reform efforts, see Developments in the LawLegal Responses to Domestic Violence, 106 HARV. L. REv. 1493, 1515-18, 1535-43 (1993).

9. See Catherine F. Klein \& Leslye E. Orloff, Providing Legal Protection for Battered Women: An Analysis of State Statutes and Case Law, 21 HofsTRA L. Rev. 801 (1993) [hereinafter Klein \& Orloff].

10. See id. at 831-43 (observing that all jurisdictions authorize some form of emergency ex parte relief upon filing a complaint for civil protection).

11. See Martha R. Mahoney, Legal Images of Battered Women: Redefining the Issue of Separation, 90 MiCh. L. REv. 1, 65-71 (1991); see also Joan Zorza, Recognizing and Protecting the Privacy and Confidentiality Needs of Battered Women, 29 FAM. L.Q. 273, 274 \& n.12-13 (1995) (observing that domestic violence escalates when victim leaves or abuser believes she is going to leave).

12. The vast majority of jurisdictions authorize the court to award temporary custody. See Klein \& Orloff, supra note 9, at n.968 (citing statutes from 42 states, the District of Columbia, and Puerto Rico); see also N.Y. FAM. CourT ACT § 842 (McKinney 1998); VA. CODE ANN. \$ 16.1-279.1(A)(7) (1998). The same is true for visitation. Klein \& Orloff, supra note 9, at n.1141 (citing statutes from 37 states and the District of Columbia); see also ALASKA STAT. $\$ 18.66 .100(C)(9)$ (Michie 1998); VA. CoDE ANN. $\$ 16.1-279.1(\mathrm{~A})(7)$ (1998). Thiry-eight states and the District of Columbia expressly authorize the award of child support in a civil protection order case. See Klein \& Orloff, supra note 9, at n.1254 (citing statutes from 36 states and the District of Columbia); see also N.Y. FAM. CourT ACT $\$ 842$ (McKinney 1998); VT. STAT. ANN. tit. $15 \$ 1103(c)(6)$ (1997).

13. See Anne L. Ganley, Domestic Violence: The What, Why, and Who, as Relevant to Civil Court Cases, in The Family Violence Prevention Fund, Domestic Violence in Civil Court Cases: A National Model for Judicial EduCation 44 (Jacqueline A. Agtuca et al. eds., 1992); Cris M. Sullivan et. al., After the Crisis: A Needs Assessment of Women Leaving a Domestic Violence Shelter, 7 VIOLENCE AND VICTIMS 267 (1992); Martha F. Davis \& Susan J. Kraham, Protecting Women's Welfare in the Face of Violence, 22 FORDHAM URB. L.J. 1141, 1155 (1995). 
potential for renewed violence is greatest during visitation, carefully structured pick-up and drop-off provisions, designed to eliminate victim-perpetrator contact, also can have a significant prophylactic effect. ${ }^{14}$

Finally, thirty-four states have adopted criminal contempt laws to help enforce protection orders, ${ }^{15}$ and forty-five jurisdictions have made violating a protection order a statutory crime. ${ }^{16}$ Effective enforcement is essential to ensure meaningful compliance; otherwise, a civil protection order becomes no more than a piece of paper that a batterer can, and often will, ignore with impunity. As one study of the civil protection order process concluded, "[e]nforcement is the Achilles' heel of the ... process, because an order without enforcement at best offers scant protection and at worst increases the victim's danger by creating a false sense of security." 17

The federal government has taken action as well. In 1994, Congress enacted the Violence Against Women Act (VAWA), ${ }^{18}$ and the "daughter of VAWA" is currently pending in Congress. ${ }^{19}$ Among other things, these laws condition state

14. Peter Finn \& Sarah Colson, U.S. Dep't of Justice, Civil Protection Orders: Legislation, Current Court Practice, and Enforcement 43-44 (1990) [hereinafter Finn \& Colson]; National Council of Juvenile \& Family Court Judges, Family Violence: Improving Court Practice 26 (1990). State gender bias task force reports have revealed that poorly structured visitation provisions are the source of a substantial portion of contempt motions brought to enforce civil protection orders. See, e.g., District of Columbia Courts, Final Report of the Task Force on Racial and Ethnic Bias and TASK Force on Gender Bias in the Courts at Appendix H at 21 (1992) [hereinafter D.C. Gender Bias TASK FORCE REPORT] (noting that such provisions accounted for $31 \%$ of contempt motions in civil protection order cases).

15. The following jurisdictions enforce civil protection orders through criminal contempt sanctions: Ala. Code § 30-5A-6; Alaska Stat. \$ 9.50.010(5) (Michie 1997); ARIZ. Rev. Stat. § 13-3602(J) (West 1998); Colo. Rev. Stat. § 18-6-803.5(7) (1998); Del. Code ANN. TTT. 11, §1271A (1997); D.C. CodE ANN. § 16-1005 (1997); FLA. STAT. ANN. \$ 741.30(8)(A) (West 1998); GA. Code ANN. § 19-13-6 (1997); Haw. Rev. Stat. § 710-1077(1)(G) (1997); 60 Ill. Comp. STat. 223(b) (West 1998); Iowa Code $§ 236.8$ (1998); Kan. STAT. ANN. § 60-3110 (1996); Ky. Rev. Stat. ANN. § 403.760(1) (Banks-Baldwin 1998); La. Rev. Stat. ANN. \& 46:2137 (West 1998); MD. Code AnN. [Family Law] § 4-508 (1997); Mich. COMP. LAws $\S 600.2950(23)$ (1998); MinN. STAT. § 518B.01(14)(F)-(G) (1997); Miss. CoDE ANN. $\S$ 93-21-21 (1998); N.H. Rev. Stat. ANN. § 173-B:8(II) (1997); N.J. STAT. ANN. § 2C:29-9 (West 1998); N.M. Stat. ANN. § 40-13-5(B) (Michie 1996); N.Y. Penal Law § 215.51(B) (McKinney 1998); N.C. Gen. STat. § 50B-4(B) (1997); N.D. Cent. Code § 14-07.1-06 (1997); Ohio Rev. Code ANN. § 2705.02 (West 1998); Or. Rev. Stat. § 107.720(4) (1997); Pa. Stat. ANn. TIT. 23, § 6114 (1998); R.I. Gen. Laws § 15-15-3(D) (1997); S.C. CodE ANN. \$ 20-4-60 (Law Co-op. 1997); TENN. Code ANN. § 36-3-610 (1997); VT. Stat. ANN. Trt.15, § 1108(E) (1997); Wash. Rev. Code $§ 26.50 .110(5)$ (1997); Connecticut v. Murray, 623 A.2d 60 (1993).

16. See Klein \& Orloff, supra note 9, at $\mathrm{n} .1835$ (citing statutes in 40 states and Puerto Rico); see also D.C. Code ANN. § 16-1005(g) (1997); Iowa Code $\S 236.8$ (1998); S.D. Codified LAW § 25-10-13 (Michie 1997).

17. FINN \& Colson, supra note 14, at 49.

18. Violence Against Women Act of 1994, Pub. L. No. 103-322, 108 Stat. 1902) (codified as amended in sections of 8 U.S.C., 16 U.S.C., 18 U.S.C., 28 U.S.C., and 42 U.S.C.). The constitutionality of this act has been questioned by a recent ruling of the Fourth Circuit. See Brzonkala v. Virginia Polytechnic Univ., 169 F.3d 820 (4th Cir. 1999). Supreme Court review is pending. Brzonkala, petition for cert. filed, No. 99-5 (June 30, 1999).

19. H.R. 3514, 105th Cong. (1998); S. 2110, 105th Cong. (1998). See Sean Scully, Scandals May Ease Renewal of Women's Act, WASH. TIMES, Mar. 20, 1998, at A9; Carl Weiser, Biden Introduces Bill to 
receipt of sizable federal funding on the creation of systems that (1) ensure that protection orders are given full faith and credit by all sister states, ${ }^{20}(2)$ provide government assistance with service of process in protection order cases, ${ }^{21}$ and (3) criminalize violations of protection orders. ${ }^{22}$ Although the specifics of protection order legislation vary from state to state and gaps in coverage for battered women certainly remain, legislation is no longer an obstacle, but a source of hope. Enormous legal strides have been made in a relatively short period of time.

The responsiveness of the criminal justice system also has improved. Although increased criminalization has become controversial as a strategic matter, ${ }^{23}$ this increase has been far more successful than most people would have thought possible ten years ago. Across the country, police are arresting offenders and prosecutors are pressing charges more frequently. ${ }^{24}$ Finally, intimate abuse is beginning to be treated as a problem with serious criminal implications. ${ }^{25}$

\section{Future Challenges in Improving the State's Response To DOMESTIC ABuse}

Despite recent improvements in the state's response to domestic violence, crucial challenges remain. I will focus on two of them here. First, how can we improve state efforts to deter crimes of intimate abuse without undermining victims' control over their lives? Second, how can we restructure the judicial system and educate individual judges so that the intolerable failure to respond to family violence is reduced?

\section{A. The Complexities of Criminalizing Domestic Violence}

Perhaps the most fundamental question raised by this symposium echoes a long-familiar ambivalence in feminist theory about state power: have recent efforts to increase state responsiveness resulted in an "overcriminalization" of domestic violence, with an almost automatic initiation of criminal prosecution occurring regardless of the needs and desires of the victim and her family? This question is complex, and no snapshot examination of the current state of affairs can provide a sufficiently nuanced answer. The issue must be examined through a

Extend Protection for Battered Women, GANNETT NEws SERviCE, Mar. 21, 1998, available in 1998 WL 5627720 .

20. See Violence Against Women Act, 18 U.S.C. $\$ 2265$ (1996).

21. See Violence Against Women Act, 42 U.S.C. $\$ 3796 \mathrm{hh}(\mathrm{c})(4)$ (1998). Domestic violence victims cite failure to accomplish service of process as one of the primary reasons for their failure to follow through on a civil protection order case. See Adele Harrell et al., Urban Institute, Court Processing and the Effects of Restraining ORders for Domestic ViolenCe Victims, 31-32 (1993).

22. See Violence Against Women Act, 42 U.S.C. $\$ 3796 \mathrm{hh}(\mathrm{c})(1)$. In order to be eligible for certain VAWA grants, state and local governments must certify that their laws or official policies "encourage or mandate arrest of domestic violence offenders who violate the terms of a valid and outstanding protection order." Id.

23. See infra notes $48-55$ and accompanying text.

24. See infra notes $26-47$ and accompanying text.

25. See id. 
lens that allows consideration of the criminal justice system's relationship with the issue of intimate abuse over time.

For many years, battered women's advocates called upon police and prosecutors to treat domestic violence like any other crime. This plea was voiced in response to the state's long-standing failure to recognize any criminal dimension to family abuse. Police officers frequently ignored domestic violence calls or delayed their response to such calls by several hours. ${ }^{26}$ When they did respond, they were trained to mediate rather than to arrest. ${ }^{27}$

The experience of the District of Columbia is typical. A study conducted in 1990 showed that the police were arresting accused batterers in only five percent of all intimate abuse cases. ${ }^{28}$ They failed to arrest in more than eighty-five percent of cases in which the victim had sustained serious injuries that were visible when the police arrived on the scene. ${ }^{29}$ Instead, police were most likely to arrest the perpetrator in situations where he insulted an officer or damaged a vehicle. $^{30}$

Activists across the country have used studies like this one to convince state legislatures to enact mandatory arrest laws. ${ }^{31}$ These statutes terminate police discretion in domestic violence cases; if probable cause exists, the officer must arrest. ${ }^{32}$ In Washington, D.C., soon after the local mandatory arrest law went into effect, police were arresting perpetrators in forty-one percent of domestic violence calls. ${ }^{33}$ This jump, from five to forty-one percent, reflects a sea change

26. See Murray A. Straus et al., Behind Closed Doors: Violence in the American Family 232 (1980); Del MARTIN, BatTEREd Wives 92 (1981).

27. As one example, Del Martin quotes the Oakland Police Department's 1975 Training Bulletin on Techniques of Dispute Intervention:

The police role in a dispute situation [is] more often that of a mediator and peacemaker than enforcer of the law... . [T] he possibility that . . . arrest will only aggravate the dispute or create a serious danger for the arresting officers due to possible efforts to resist arrest . . . is most likely when a husband or father is arrested in his home. . . Normally, officers should adhere to the policy that arrests shall be avoided . . . but when one of the parties demands arrest, you should attempt to explain the ramifications of such action (e.g., loss of wages, bail procedures, court appearances) and encourage the parties to reason with each other.

MARTIN, supra note 26, at 93-94.

28. See Sandra Jean Sands et al., Police Response to Domestic Violence, in INSTTUTE fOR WoMEN's Policy Research Second Annual Women's Policy Conference (June 1990) (on file with author).

29. See id.

30. See id.

31. For example, the District of Columbia enacted its mandatory arrest law in 1991. D.C. CODE ANN. § 16-1031-34 (1991).

32. See id.

33. See National Center for State Courts, Civil Protection Orders: The Benefits and Limitations FOR VICTIMS OF DOMESTIC VIOLENCE 49 (Susan L. Keilitz et al. eds., 1997) [hereinafter NCSC CIVIL PROTECTION ORDER STUDY] (reporting a study of women who received civil protection orders in Delaware, Denver, and the District of Columbia). This study focused exclusively on police response vis-a-vis male perpetrators. Among other things, it does not reflect the problematic increase in dual arrests - police arrest of both victim and batterer - that activists have noted across the country. See, e.g., Donna M. Welch, Mandatory Arrest of Domestic Abusers: Panacea or Perpetuation of the Problem of Abuse?, 43 DePaul L. REv. 1133, 1159 (1994). A recent General Order issued by the D.C. Metropolitan Police Department attempts to eradicate this practice by directing officers to distinguish 
for victims of family abuse. Putting the problem of unwilling victims aside for the moment, those who seek access to the criminal justice system are far more likely to succeed with the advent of mandatory arrest. ${ }^{34}$

But mandatory arrest policies alone have not been sufficient. Even when presented with more domestic violence arrests, prosecutors nationwide rarely pressed charges, and when they did, they rarely followed through with the case. In the District of Columbia, for example, the charging rate was approximately fifteen percent of arrest cases, and very few of these proceeded to plea or trial. ${ }^{35}$ The low prosecution rates were the result of a special policy for intimate abuse cases, in which charges would be dropped at the victim's request, at any time, with no questions asked. The rationale was the belief that convictions could not be obtained without victim cooperation and testimony. Although some prosecutors recognized that batterers were pressuring victims into making the request to drop the charges, they claimed that they could not distinguish between a battered woman who was communicating her true feelings and one who had a literal or figurative gun to her head. ${ }^{36}$ Thus, they adopted a uniform approach and dropped charges in every case.

This "automatic drop" policy ceded to perpetrators an enormous degree of control over the criminal justice process. All a batterer had to do was coerce his victim-through violence or threats of violence-into asking the prosecutor to drop the charges; once she did so, the risk of incarceration instantly vanished.

During the 1980s and 1990s, victim advocates lobbied aggressively to change these policies, and they have finally begun making inroads in a growing number of jurisdictions. ${ }^{37}$ Still citing the difficulty in distinguishing between those who "really" want to drop charges and those who do not, many prosecutors have adopted "no-drop" policies, pursuant to which a case proceeds regardless of the victim's wishes, as long as sufficient evidence exists to prove criminal conduct. ${ }^{38}$

Early data indicate that these no-drop policies yield substantial positive results,

between the primary aggressor, who must be arrested, and a person who may have inflicted injury on another, but who did so in self-defense. Wash., D.C., Metro. Police Dep't Gen. Order 304.11, Intrafamily Offenses, at 10-12 (Jan. 12, 1998). No data yet exist, however, from which to determine whether the General Order has resulted in a decrease in dual arrests.

34. The issue of unwilling victims is discussed infra notes 48-55 and accompanying text.

35. See, e.g., Sam Skolnik, Confronting Domestic Violence: D.C.'s Once Shoddy Record Much Improved, LEGAL TIMES, Aug. 18, 1997, at 14 (citing a 10-30\% charging rate).

36. In the District of Columbia, for example, one prosecutor spent every day for six months interviewing victims of intimate abuse who sought to drop charges. Interview with Robert Spagnoletti, Chief, U.S. Attorney's Office Domestic Violence Unit, in Washington, D.C. (Sept. 3, 1997). He found that he was unable to distinguish between those who were responding to a direct threat and those who were not. Id. When he refused to honor victims' requests to drop a case, many of them called him later to explain that they had been threatened into making the request against their will and to thank him for pursuing the prosecution. Id.

37. In a recent survey, $66 \%$ of prosecutor's offices in major urban centers reported that they had adopted such policies. See D.J. Rebovich, Prosecution Response to Domestic Violence: Results of a Survey of Large Jurisdictions, in Do ARRESTS AND RESTRAINING ORDERS WORK? 176, 182-83 (Buzawa \& Buzawa eds., 1996).

38. See infra notes 41-47. 
including the reduction of homicides. In San Diego, for example, officials found that under the old policy levels of violence increased when abusers learned that a case would be dismissed if the victim refused to cooperate..$^{39}$ In 1985 , however, the city implemented a no-drop policy and domestic homicides fell from thirty in 1985 , to twenty in 1990 , to seven in $1994 .{ }^{40}$ No-drop policies also appear to lower recidivism and strengthen the message that intimate abuse will not be tolerated. $^{41}$

After years of community pressure in the District of Columbia, the U.S. Attorney's Office finally adopted an aggressive approach to prosecution, including a no-drop policy. ${ }^{42}$ Prosecutors assigned to the newly-created Domestic Violence Unit view intimate violence as a crime against the state and seek to vindicate the government's interests regardless of the individual victim's wishes. Perpetrators no longer are able to manipulate the system by coercing the victim into dropping the charges; control has been shifted from the perpetrator to the government.

As in San Diego, D.C.'s no drop-policy led to a radical shift in domestic violence prosecutions. In 1989, the office prosecuted approximately five misdemeanor cases out of 19,000 family abuse calls to 911 emergency services. ${ }^{43}$ From 1996-1997, the first year of the new regime, the Domestic Violence Unit filed approximately 6,000 misdemeanor cases. ${ }^{44}$ The statistics for the following year are closer to $8,000 .{ }^{45}$ An even more telling statistic is that the Unit now presses charges in approximately sixty-seven percent of arrest cases, precisely the same rate as in stranger violence arrests. ${ }^{46}$ Similarly, the conviction rate in domestic violence cases now closely approximates that in other misdemeanor non-jury trials in the District of Columbia, ranging between sixty-five and sixty-seven percent. ${ }^{47}$

Mandatory arrest laws and no-drop prosecution policies have moved domestic

39. See Casey G. Gwinn \& Anne O'Dell, Stopping the Violence: The Role of the Police Officer and the Prosecutor, 20 W. ST. UNIV. L. REv. 297, 310 (1993).

40. See Mark Hansen, New Strategy in Battering Cases, A.B.A. J., Aug. 1995, at 14.

41. See Cheryl Hanna, No Right to Choose: Mandated Victim Participation in Domestic Violence Prosecutions, 109 HARV. L. REv. 1849, 1852-53, 1864-65 (1996).

42. The Office also adopted a vertical prosecution policy, where a single prosecutor is assigned to a case from beginning to end. Most other misdemeanors are prosecuted "horizontally," with a different prosecutor handling each stage of the litigation. Vertical prosecution encourages the development of a continuing relationship between attorney and complaining witness that can contribute to better victim follow-through.

43. See Sands et al., supra note 28 , at 1.

44. Interview with Robert Spagnoletti, supra note 36. This statistic is derived from the fact that the Domestic Violence Unit prosecuted approximately 6,400 cases over the 13-month period from April 1, 1996 to April 30, 1997; the number given is the 12-month average.

45. See id.

46. See Skolnik, supra note 35 , at 14.

47. See Letter from Duane B. Delaney, Clerk of the Court, to Andrew P. McGuire (June 23, 1997) (on file with author); Interview with Robert Spagnoletti, supra note 36. Prior to institution of the new domestic violence court, prosecutors estimate that the conviction rate in domestic violence trials was $20 \%$, less than a third of the current rate. See Skolnik, supra note 35, at 14. 
violence criminal prosecutions to a position of rough parity with crimes perpetrated by non-intimates, and have expanded greatly the tools available to battered women seeking to escape abuse. In addition, these forms of targeted criminal legislation carry a degree of symbolic power and moral authority for which civil rulings can offer no real equivalent. The concept of treating family abuse "like any other crime" is finally within reach.

But by embracing the state as an ally, victims find themselves seeking redress from a criminal justice system that can perpetuate the kinds of power and control dynamics that exist in the battering relationship itself. In many cases, prosecutors take complete control over the case, functioning as the sole decision-maker and ignoring the victim's voice, wishes, and ideas. If a victim changes her mind mid-way through the litigation and seeks to drop charges so that the father of her children can continue to work and provide financial support, a prosecutor may refuse to do so, on the ground that this would not serve the interests of the state in punishing violations of the social contract. ${ }^{48}$ Such revictimization can thwart the survivor's efforts to regain control over her life and move past the abusive experience.

Increased intervention by the criminal justice system has been particularly problematic for many subgroups of victims, in particular immigrant populations $^{49}$ and racial minorities. ${ }^{50}$ For example, recent reforms in United States immigration laws create strong disincentives for immigrant women to press criminal charges against their batterers. The new laws dictate that an immigrant convicted of a domestic violence offense, stalking, or a protection order violation becomes deportable, even if he has previously obtained lawful permanent resident status. ${ }^{51}$ Many women are reluctant to expose their partners to the risk of deportation, and be ostracized from their communities for doing so, particularly if the perpetrator might be subjected to political persecution if forced to return to his home country. Deportation of a batterer also may adversely affect the victim's own petition for legal residency. ${ }^{52}$

Similarly, women of color often choose to remain silent about abuse.

48. A prosecutor dealing with a reluctant victim in a domestic violence case faces a difficult dilemma. Does a dismissal of an individual case based on the victim's wishes occur at the expense of the public good of punishing criminal conduct and deterring future violence? Does a failure to honor a victim's wishes result in a revictimization by subjecting her to further coercion at the hands of the state? For an excellent discussion of these issues within a feminist theory framework, see Hanna, supra note 41, at 1988-89; see also Donna Wills, Domestic Violence: The Case for Aggressive Prosecution, 7 UCLA WOMEN's L.J. 173 (1997).

49. See generally, Tien-Li Loke, Note, Trapped in Domestic Violence: The Impact of U.S. Immigration Laws on Battered Immigrant Women, 6 B.U. PUB. INT. L.J. 589 (1997).

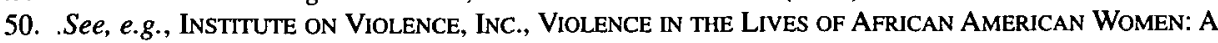
Focus Group StUdy 18-19 (Beth E. Richie ed., 1996) [hereinafter VIOLENCE IN THE LIVES OF AFrICAN AMERICAN WOMEN].

51. See Illegal Immigration Reform and Immigrant Responsibility Act, Pub. L. No. 104-208 $\$ 350$ (1996) (amending 8 U.S.C. $§ 1251(a)(2)$ ).

52. Tien-Li Loke, supra note 49, at 616. Although the Violence Against Women Act has reduced the scope of this problem, it has not been entirely eliminated. See id. 
Kimberle Crenshaw, whose writing explores the "intersectionality" of experiences of racism and sexism on battered women of color, argues:

Women of color are often reluctant to call the police, a hesitancy likely due to a general unwillingness among people of color to subject their private lives to the scrutiny and control of a police force that is frequently hostile. There is also a more generalized community ethic against public intervention, the product of a desire to create a private world free from the diverse assaults on the public lives of racially subordinated people. The home is not simply a man's castle in patriarchal sense, but may also function as a safe haven from the indignities of life in a racist society. ${ }^{53}$

In an extensive focus group study in New York, African American participants expressed the view that reporting batterers to the police was a breach of loyalty, since such reporting could further contribute to the social stereotyping of black men as particularly violent. ${ }^{54}$ In one woman's words, "the ideas behind ... how Black boys are feared by White people, and how police beat Black men ... it's a bad time to be Black and it's an even worse time to talk about the problems we face in our community." 55

\section{B. Possibllities for Progress}

How can we find a satisfactory way to enhance deterrence of intimate abuse while adequately protecting the safety and autonomy of individual victims and reducing their reliance on historically discriminatory state institutions? A promising development is the extensive common ground between two symposium speakers who ultimately reach opposite conclusions: Robert Spagnoletti, Chief of the D.C. U.S. Attorney's Office Domestic Violence Unit and a strong supporter of mandatory arrest and no-drop prosecution, ${ }^{56}$ and Professor Linda Mills, known for her empathic, victim-centered work and opposition to increased criminalization. ${ }^{57} \mathrm{Mr}$. Spagnoletti explains that he adopted a no-drop prosecution policy because he found it impossible to distinguish between victims who genuinely

53. Kimberle Crenshaw, Mapping the Margins: Intersectionality, Identity Politics, and Violence Against Women of Color, 43 STAN. L. REv. 1241, 1257 (1991).

54. See VIOLENCE IN THE LIVES OF AFRICAN AMERICAN WOMEN, supra note 50, at 18-19; see also Beth Richie, Battered Black Women: A Challenge for the Black Community, THE BLACK SCHOLAR, Mar.-Apr. 1985 , at $40,43-44$.

55. Id. at 18-19.

56. Robert Spagnoletti, Remarks at First Annual Gender, Sexuality, and the Law Symposium: Hate Crimes, Domestic Violence, and State Accountability (Feb. 20-21, 1998) (transcript on file with THE GEORGETOWN JOURNAL OF GENDER AND THE LAw) [hereinafter SYMPOSIUM].

57. See, e.g., Linda G. Mills, Remarks at Symposium (transcript on file with ThE GeORGETOWN Journal OF GENDER AND THE LAW); Linda G. Mills, Intuition and Insight: A New Job Description for the Battered Woman's Prosecutor and Other More Modest Proposals, 7 UCLA Women's L.J. 183 (1997); Linda G. Mills, On the Other Side of Silence: Affective Lawyering for Intimate Abuse, 81 CORNELL $\mathbf{L}$. REV. 1225 (1996). 
wished to drop charges and those who were being coerced. ${ }^{58}$ Professor Mills claims that we can, and must, learn to make such distinctions by adopting a variety of victim-centered intervention policies. These positions differ less in principle than in rhetoric and in perspective on the availability of resources.

The common ground lies, at least in part, in an increased focus on the role that private individuals and communities can play in diminishing the incidence of violence and the need for state intervention, and in ensuring that the victim plays a greater role in those cases in which government response remains necessary. A growing body of research indicates that civil society has an important role to play here.

A recent study in East Lansing, Michigan, ${ }^{59}$ for example, compared two groups of battered women leaving a domestic violence shelter. One was a control group; in the other, each woman was assigned a college student volunteer who served as her advocate for six hours a week, over a ten-week period. ${ }^{60}$ The advocates had no prior experience working in the domestic violence field, but received ten weeks of training before embarking on the project. ${ }^{61}$ Each student worked with a woman to help her assess her personal needs and goals, and then assisted her in obtaining limited or difficult to access community resources. ${ }^{62}$ These resources included housing, employment, legal assistance, transportation, child care, health care, counseling for the children, and social support. ${ }^{63}$

Both groups of women were interviewed every six months for two years. ${ }^{64}$ Women in the advocacy group reported less physical violence-in fact, over twice as many women in the advocacy group experienced no violence whatsoever during the two-year period. ${ }^{65}$ These women also experienced less depression and a higher quality of life, and those who wished to end their abusive relationships were more effective in doing so. ${ }^{66}$ Of particular importance is the fact that women with advocates perceived themselves as significantly more effective in obtaining community resources and assistance as well as interpersonal social support. ${ }^{67}$

Similar results were reached in a study of the role of social support from family, friends, neighbors, and coworkers in determining victim follow through in domestic violence criminal prosecutions. ${ }^{68}$ Where "follow through" was

58. See supra note 56.

59. See Chris Sullivan et al., Promising Findings of a Community-Based Advocacy Project for Women with Abusive Partners: Two-Year Follow-up, J. Consulting AND ClinICAL PsYCH. (forthcoming 1999) (copy on file with author).

60. See id. at 12.

61. See id. at 27.

62. See id.

63. See id.

64. See id.

65. See id. at 26-27.

66. See id. at 19.

67. See id. at 21 . All of these differences were found to be statistically significant. See id.

68. See Lisa A. Goodman et al., Obstacles Women Face in Prosecuting their Batterers: The Role of Social Support, VIOLENCE AND VICTTMS (forthcoming 1999) (copy on file with author). 
defined as cooperating in the prosecution of a batterer (after the initial decision to press charges) by providing necessary information to prosecutors and expressing a willingness to testify, ${ }^{69}$ survivors able to access more interpersonal support were approximately twice as likely to cooperate voluntarily with the prosecution. $^{70}$

These results are quite exciting. They indicate that, in many cases, an increase in victim support from family, friends, and trained personnel can be enough to empower victims to exit the cycle of violence. Advocacy services apparently reduce some victims' dependency on the criminal justice system, by helping them find the strength to escape on their own. And for those who need prosecutorial intervention, the presence of an advocate or supporter enables them to better assert themselves in obtaining the help they need. By amplifying victims' voices, advocates can help the government better respond to individual concerns, and better discern those cases in which the survivor seeks to drop charges because of a considered decision that the course of action is best for herself, her family, and the larger community to which she belongs. Certainly, domestic violence is a crime against the state and generally should be treated as such; but victim advocates could be a key to transforming one-size-fits-all prosecution policies into responses that also are tailored to the concerns of individual women. ${ }^{71}$

These studies and others like them indicate that as we work to increase state accountability for violence, we must put equivalent energy into providing individual advocates and creating communities that can provide victims more social support. In so doing, we may lessen the need for state intervention and, where such intervention is necessary, amplify victims' voices to enable the state to better respond to individual concerns.

69. See id. at $1-2$.

70. See id. at 20.

71. Another source of hope comes from a recent study on the relationship between the economic sustainability of communities and the prevalence of violence. Robert J. Simpson, Neighborhoods and Violent Crime: A Multilevel Study of Collective Efficacy, 277 SCIENCE 918 (Aug. 15, 1997). The authors looked at 350 neighborhoods of diverse racial, ethnic, and socioeconomic composition within the city of Chicago. They measured the relationship between the frequency and degree of violence in each neighborhood and the prevalence of informal social control mechanisms used by local residents to ensure public order. The study was not focused specifically on domestic abuse, but the conclusions appear to be applicable to all forms of violence, whether perpetrated by strangers or intimate partners. "Informal social control" was defined to include such actions as intervening to prevent teenage peer groups from hanging out on street corners and confronting people threatening violence in public spaces. The study shows that, after controlling for all demographic factors, higher levels of informal social control are a strong predictor of lower levels of violence. And the major factors facilitating informal social control include, predictably, the degree of residential and economic stability in the community. A similar study of cities across the country found that those which had lost manufacturing jobs most rapidly between 1963 and 1990 had far higher rates of violent crime than those which had gained such jobs most rapidly. See Barry Castro, Manufacturing Jobs, Local Ownership, and the Social Health of Cities-A Research Note, The Responsive Community, Winter $1997 / 98$, at 63,64 . Thus, by finding ways to bolster the economic sustainability of communities, we may be able to reduce violence and, in turn, the need for criminal prosecution. 


\section{The Role of the Judicial Branch}

The current debate about state accountability for intimate violence has focused primarily on the legislative and executive branches of government. Questions arise about the appropriate legislative response to domestic abuse and whether and to what extent the federal government should play a role in regulating an area traditionally left to the states. Local, regional, and national conferences are being held to discuss implementation strategies adopted by the executive branch, in the form of police department arrest protocols and prosecutorial no-drop policies. Far less attention has been paid to the possibilities offered by the third branch of government-the judiciary. A fundamental restructuring of the traditional justice system's approach to the social problem of domestic abuse is, in my view, the critical next generation of work needed to improve the state's response.

The ability of the judicial system to deal with specialized forms of violence matters at least as much as the applicable substantive law. Improvements on the legislative front are doomed if judges continue to view these issues as private matters that do not belong in a courtroom, or actions that are not "really" criminal in nature.

Domestic violence activists have recently begun to focus on judicial reform, and the District of Columbia has been a leader in this movement. In November 1996, the District inaugurated a new, integrated Domestic Violence Court, in which a small number of trained judges are assigned to spend a year hearing civil protection order cases, prosecutions of crimes between intimates, and family law matters between parties where an active protective order is in place. Many interesting issues have grown out of this reform experiment, but one of the most important is the effort to combat a general failure of judicial neutrality in domestic violence cases.

Most judges come to the bench with no real understanding of the social and psychological dynamics of domestic violence and, instead, bring with them a lifetime of exposure to the myths that long have shaped the public's attitude toward the problem. The most persistent of these myths is the belief that intimate abuse is somehow acceptable, or at least insignificant, and therefore not deserving of a serious public response, and the belief that battered women could leave their relationships with relative ease if they simply chose to do so. Lack of information about these basic aspects of domestic violence causes many judges to become frustrated with petitioners whom they perceive as filing inappropriate cases and "refusing" to leave abusive relationships. State gender bias task forces across the country consistently report that the result is a persistent anti-victim bias among judges hearing family violence cases. ${ }^{72}$

72. When cases are brought by women who have dropped charges on previous occasions, judges have made such comments as: "Oh, it's you again;" "How long are you going to stay [away] this time;" or "You want to go back and get beat up again?" MaRYLAND SPECIAL JoInt CommitTeE, Gender Bias IN THE Courts: Report of The Special Joint Commitree on Gender Bias in the Courts 8 (1989) (footnote omitted). Others have gone so far as to threaten victims with sanctions for repeated use of the 
For example, in 1994, Kenneth Peacock found his wife in bed with another man. Several hours later, he shot her in the head with a hunting rifle. ${ }^{73}$ When Peacock pleaded guilty to voluntary manslaughter, the Maryland judge who presided over his case commented, "the most difficult thing that a judge is called upon to do ... is sentencing noncriminals as criminals." 74 He imposed an eighteen-month sentence, to be served on a work release program, which allowed Peacock to reenter the community within two weeks of sentencing. ${ }^{75}$ In another case, a Florida judge heard testimony that a man had doused his wife with lighter fluid and set her on fire. The judge burst into song in open court crooning, "You light up my wife," to the tune of "You Light Up My Life." judge began a hearing with the comment, "Well, well, well, we had a little domestic squabble, did we? Naughty, naughty. Let's kiss and make up, and get out of my court." 77 These are just a few, particularly egregious examples culled from numerous gender bias task force reports. They may be somewhat atypical in terms of the extent of the insensitivity exhibited, but they demonstrate how deeply ingrained the problem is.

The District has attempted to respond to this problem by requiring judges on the new Domestic Violence Court to undergo formal judicial training on intimate abuse. These judges must also accept a year-long assignment, which allows them to build a reservoir of experience in the area. Although the training opportunities have been sorely limited, the advocacy community already has witnessed substantial positive changes in judicial treatment of these cases. A telling example lies in the change in judicial response to requests for custody and child support in civil protection order cases. As discussed in Part I, rapid resolution of these issues is of extreme importance in domestic violence cases, where perpetra-

court system. See id. A particularly egregious example occurred in North Dakota, where a judge is reported to have told a domestic violence petitioner, "If you go back [to the perpetrator] one more time, I'll hit you myself." Gender Fairness, 72 N. DAK. L. REv. 1113, 1208 (1996).

73. See Karl Vick, Maryland Judge Taking Heat in Cuckolded Killer Case, WASH. Post, Oct. 30, 1994, at $\mathrm{A} 1$.

74. Reporter's Official Transcript of Proceedings (Sentencing) at 4-5, State v. Peacock (Md. Cir. Ct. Oct. 17, 1994) (No. 94-CR-0943), cited in Lynn.Hecht Schafran, There's No Accounting for Judges, 58 AlBANY L. REv. 1063, 1063 (1995).

75. See id. at 20-21. The judge further ordered Peacock to perform fifty hours of community service in a domestic violence program. See Schafran, supra note 74, at 1064 \& n.14. As Schafran points out:

Sentencing in domestic violence and sexual assault cases often includes highly misguided requirements that defendants work in battered women's shelters or rape crisis centers, which are the least appropriate placements for these type[s] of offenders. Victim empathy does not come from proximity to victims but from long, intensive, painful treatment in specialized batterers' and sex offenders' programs.

Id. (citations omitted).

76. See Supreme Court of the State of Florida, Report of the Florida Supreme Court Gender Bias Study Commission 121 (1990) (citing Debbie Boone, You Light Up My Life, on Best of DebBiE BoONE (Curb Records 1990)).

77. Report of the New York Task Force on Women in the Courts, 15 FORDHAM URB. L.J. 1, 36 (1986-87) (footnote omitted). 
tors commonly use financial leverage to manipulate and control their victims.

Prior to the Domestic Violence Court's formation, D.C. judges awarded temporary custody in fewer than half of the civil protection order cases in which the parties had a child together, despite clear statutory authorization to grant such relief. ${ }^{78}$ Further, they awarded child support in only $2.6 \%$ of civil protection order cases where the parties had a child together, and $4.9 \%$ of those cases involving a custody order, ${ }^{79}$ although such an award is authorized by statute and case law. ${ }^{80}$ This kind of track record is typical nationwide; forty-three percent of domestic violence service providers report that judges are unwilling to consider awarding remedies that are clearly authorized by statute, especially custody, child support, and other forms of financial relief. ${ }^{81}$

In the new Domestic Violence Court, however, judges now routinely award custody based on the best interest of the child standard as well as child support based on D.C.'s financial guidelines. Judges even occasionally take the time to talk to people who appear before them about the harmful impact that witnessing adult-on-adult abuse can have on children and about the intergenerational nature of domestic violence.

In my view, this counts as a substantial success, far beyond what I believed possible. I am beginning to conclude that targeted judicial education can be an extraordinarily effective means of accomplishing social change. The judiciary is a relatively small population to work with in the effort to debunk larger societal mythologies and stereotypes, and every judge who gains a broader understanding of the issue can have an impact on a large number of families who appear before her. Therefore, judicial training and court reform is a crucial next step if we seek to deliver on the promise of the new generation of domestic violence legislation.

\section{CONCLUSION}

The domestic violence movement has been one of the most successful sociopolitical movements of this century. The past thirty years have witnessed not only enormous improvements in societal consciousness-raising, but also a dramatically improved state response, through the availability of legal remedies and the responsiveness of the criminal justice system. But new challenges accompany this increase in the focus of state power. As the police grow more likely to arrest and prosecutors grow more likely to press charges, we must find new and innovative ways to ensure that victims' voices are not silenced and that survivors are not forced to sacrifice their autonomy in exchange for government assistance. In addition, renewed energy must be focused on helping judges purge

78. See D.C. Gender Bias TASK ForCe RePort, supra note 14, at 147; D.C. CodE ANN. \$ $16-1005(c)(6)$ (1998).

79. See D.C. Gender Bias TASK ForCe Report, supra note 14, at 148.

80. See D.C. Code ANN. § 16-1005(c)(10) (1998); Powell v. Powell, 547 A.2d 973 (D.C. 1988).

81. See Kit Kinports \& Karla Fischer, Orders of Protection in Domestic Violence Cases: An Empirical Assessment of the Impact of the Reform Statutes, 2 TEx. J. WOMEN \& L. 163, 205-07 (1993). 
the stereotypes they bring to the bench, comprehend the dynamics underlying intimate abuse, and deliver appropriate relief. Activists must continue to press the state to respond to the intimate abuse crisis, while simultaneously shoring up support for individual victims. 
. 